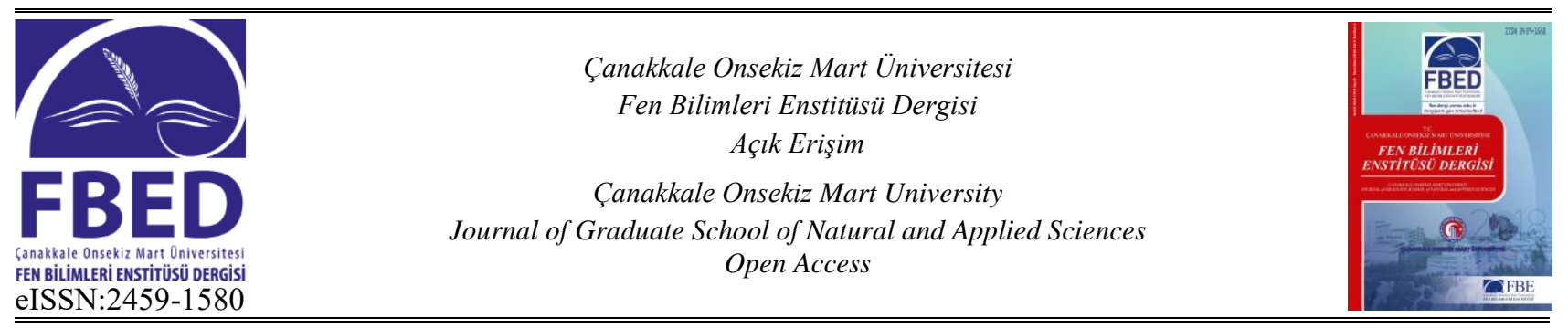

\title{
İşyerlerinde Ramak Kala Bildirimlerinin İş Kazalarına Etkisi ve İnşaat Sektöründe Uygulama
}

\author{
Mehmet PIŞKİN ${ }^{1}$, Orkun DALYAN ${ }^{2, *}$ \\ ${ }^{1}$ Gıda İşleme Bölümü, Çanakkale Teknik Bilimler Meslek Yüksek Okulu, Çanakkale Onsekiz Mart Üniversitesi, Çanakkale, Türkiye \\ ${ }^{2}$ İş Güvenliği Anabilim Dalı, Fen Bilimleri Enstitüsü, Çanakkale Onsekiz Mart Üniversitesi, Çanakkale, Türkiye
}

\begin{abstract}
Makale Tarihçesi
Gönderim: $\quad 23.08 .2019$

Kabul: $\quad 08.04 .2020$

Yayım: $\quad 22.05 .2020$
\end{abstract}

Arașturma Makalesi

\begin{abstract}
Öz - İş kazaları Türkiye'de olduğu kadar Dünyada da önemli bir sorun olarak karşımıza çıkmaktadır. İs kazalarının gerçekleşmeden önce önlenmesi, proaktif yaklaşımın temelidir. Ramak kala olaylar, iş kazalarının önceden tahmin edilmesini sağlayacak proaktif yöntemlerden en önemlisidir. Daha önce yapılmış olan kaza piramidi çalışmaları, ramak kala (near miss) bildirimlerinin önemini vurgulamaktadır. Bu çalışmanın amacında ise çalışanların ramak kala olaya ilişkin bilgi ve algı düzeylerinin çalışanların demografik özelliklerine göre etkileri tespit edilmiştir. Çanakkale ili kapsamında inşaat şantiyelerinde görevli personeller tarafından cevaplandırılmak üzere bir anket çalışması düzenlenmiştir. 125 çalışan tarafından cevaplandırılan anket verileri Sosyal Bilimler için İstatistik Programı (SPSS) 22.0 ile analiz edilmiştir. Araştırmaya katılan çalışanların 118'i (\%94.4) erkek, 87'si (\%69.6) bekârdır. Katılımcıların 98'i (\%78.4) lise ve üzeri düzeyde eğitim almıștır. Katılımcıların sadece 8'i (\%6.4) 50 yaş üzerindedir. Katılımciların 50'si (\%40.0) 3 yıldan az, 58'i (\%46.4) 3-5 yıl arası ve 17'si (\%13.6) 5 y1ldan fazla mesleki tecrübeye sahiptir. Elde edilen verilere göre, katılımcıların\%50'sinden fazlasının bildirim sisteminin varlığı, gerekliliği ve iş kazaları arasındaki bağlantıların varlığı hakkında "bilmiyorum" diye cevap verdiği belirlenmiştir. Diğer yandan; katılımcıların eğitim düzeyi ve mesleki tecrübe süresi değişkenleri ile ramak kala olay bilgi düzeyleri arasında anlamlı bir ilişki saptanamamıştır. Ancak cinsiyet, medeni durum ve yaş değişkenleri ile ramak kala olay bilgi düzeyi arasında anlamlı bir ilişki olduğu sonucuna ulaşılmıştır. Çalışma sonucunda elde edilen veriler ve analiz sonuçları ışığında, çalışanların ramak kala olay bilgisi ve farkındalığının arttırılmasını sağlayacak çalışmaların planlanması ve böylece daha güvenli iş yerlerinin oluşturulmasına katkı sağlayacağı önerilmektedir.
\end{abstract}

\section{The Impact of Near Miss Notices on Occupational Accidents at Work- places A Study from Construction}

\footnotetext{
${ }^{1}$ Department of Food Processing, Vocational School of Technical Sciences, Çanakkale Onsekiz Mart University, Çanakkale, Turkey
} ${ }^{2}$ Department of Occupational Safety, Graduate School of Natural and Applied Sciences, Çanakkale Onsekiz Mart University, Çanakkale, Turkey

Article History

Received: $\quad 23.08 .2019$

Accepted: $\quad 08.04 .2020$

Published: $\quad 22.05 .2020$

Research Article

\begin{abstract}
Work-related accidents, as in Turkey emerges as an important issue in the world. Prevention of work accidents before occurrence is the basis of the proactive approach. Near miss events are the most important of the proactive methods for predicting work accidents. The purpose of this study was to determine the effects of knowledge and perception levels regarding the incident according to the demographic characteristics of the participants. For this purpose, a survey has been applied. The survey data answered by 125 employees were analyzed by the Statistical Program for Social Sciences (SPSS) 22.0. Of the employees surveyed, 118 are man and 87 are single. 98 of the participants have high school or higher education. 8 of the attendants are over 50 years of age. Of the participants, 50 people have less than 3 years, 58 people between 3 and 5 years, and 17 people have more than 5 years of professional experience. In the light of the data obtained, it was determined that more than $50 \%$ of the participants answered that "I don't know" about the presence of the notification system, its necessity and the presence of connections between work accidents. On the other hand; no significant relation was found between the variables in the education levels and professional experience of the participants and their level of near miss event information. In contrast, it was determined that there was a significant relationship between variables such as gender, marital status and age and the level of near miss event information. The research details will make contribution to the planning of studies and the creation of safer workplaces to increase employee incident information and awareness.
\end{abstract}

Keywords - Occupational safety, occupational accidents, accident pyramid, proactive approach, near miss

\footnotetext{
(D) https://orcid.org/0000-0002-4572-4905 mehmetpiskin@comu.edu.tr

2 (D) https://orcid.org/0000-0003-4791-9084 orkundalyan@outlook.com

*Sorumlu Yazar / Corresponding Author
} 


\section{Giriş}

Sanayileşme ve teknolojik gelişmeler ile beraber çalışan nüfus artmaya başlamıştır. Farklı iş prosesleri, makineye dayalı üretim ve çeşitlenen çalışma ortamı sonucunda iş hayatı tehlikeli ve riskli bir ortam haline gelmiştir (Özpınar, 2018). Tehlike ve risklerin yönetilmemesi durumunda yaralanmalar, ölümler ve ciddi maddi kayıplar yaşanabilmektedir. Bahsi geçen tüm uygunsuzlukların giderilmesi ve hatta risk meydana çıkmadan önlem alınması düşüncesi iş sağlığı ve güvenliği (ISG) kavramını doğurmuştur. İSG kavramı, işyerindeki personellerin, diğer kişilerin (sürekli olmayan iş için gelen personeller, alt yüklenici firma personelleri vb.) veya ziyarete gelen kişilerin de sağlık ve güvenliğini etki eden ya da etkileyebilecek koşullar ve durumlar olarak belirtilmiştir (Türk Standartları Enstitüsü, 2008). İSG sürdürülebilir iyi çalışma koşulları ve güçlü önleyici güvenlik kültürlerinin elde edilmesinde kilit bir unsurdur (Alli, 2008). Personellerin çalışma ortamında karşılaşabileceği risklere karşın her türlü önlemi almak, belirtilen önlemler için gerekli teçhizatı sağlamak İSG açısından önemlidir. (Tan ve Çalışkan, 2018). Bahsi geçen İSG önlemleri alınmadığı taktirde iş kazası kaçınılmaz olacaktır.

İş kazaları Türkiye'de olduğu kadar Dünyada da önemli bir sorun olarak karşımıza çıkmaktadır. Uluslararası Çalışma Örgütü (ILO)'ne göre iş kazası, sonucu ölüm olan ya da olmayan, personellerin yaralanmasına neden olan ve iş illiyetti bulunan durumları kapsamaktadır (Koçak, Eravcı, Ayan, Çelik ve Akaner, 2018). Dünya Sağlı Örgütü (WHO)'ne göre iş kazası, plansız olarak ortaya çıkan, yaralanma ya da işyerindeki ekipmanı zarara uğratan ve imalatın aksamına sebep olan olay olarak tanımlanmaktadır (WHO, 2017). İş kazası, mevzuatımızda; çalışma alanı içinde meydana gelen, personelleri fiziksel ya da psikolojik olarak engelli hale getirebilecek olaylar şeklinde açıklanmıştır (6331 Sayılı ISSG Kanunu madde 3/g). Hangi kazaların iş kazası kapsamına girdiği ise 5510 sayılı Sosyal Sigortalar ve Genel Sağlık Sigortası (SGK) Kanunda detaylı şekilde tanımlanmıştır. 5510 sayılı kanuna göre; çalışanın işyerinde bulunduğu sırada, çalışanın iş yürüttüğü esnada, işveren tarafından işyeri dışına görevli olarak gönderildiğinde, emziren kadın kategorisindeki çalışanların çocuğuna süt verme aralı̆̆ında ve işverence sağlanmış olan serviste işe gidiş-geliş sürelerinde yaşanan kazalar iş kazası sayılmaktadır (5510 SGK Kanunu madde 13). İş kazaları, sadece çalışanların zarar görmesine ya da can kaybına değil işletme içerisindeki makinaların, proseslerin zarar görebilmesine, malzeme veya ekipman kayıplarına neden olmaktadır (Özkılıç, 2005). Oluşabilecek iş kazası sonucunda çalışan, işveren ve ülke ekonomisi ekonomik yönden de zarar görebilmektedir (Yenisarı, Mestav ve Öztürk, 2019). İş kazalarının nedenlerinin tespitinde birçok çalışma yapılııştır ancak genel olarak iş kazalarının sebeplerinin \%88'i güvenli olmayan davranış, \%10'u güvenli olmayan durum ve \%2'si önlenemeyen durumlar olduğu dünya çapında kabul gören bir görüştür (Anonim, 2011). İş kazaları temelde insan davranışından kaynaklanmayan tehlikeli ortamdan, insan davranışından kaynaklanan tehlikeli eylemden ya da her ikisinin birleşmesi sonucu oluşmaktadır (Selek Öz ve Nam, 2018). İş kazalarının önlenebilmesi için çeşitli yaklaşımlar mevcuttur. Yaşanmış olan iş kazalarının nedenlerinin araştırılması, kök-neden analizlerinin yapılması yaygın kullanılan bir yöntemdir. Bir önceki yıla ait iş kazası verileri kullanılarak iş kazası sıklık ve ağırlık oranları hesaplanmakta ve gelecek yıldaki yaşanabilecek iş kazası oranları yaklaşık olarak tahmin edilebilmektedir (Yılmaz, 2013). Ancak bahsi geçen yaklaşım bir iş kazasının yaşanmış olması sebebiyle olaydan sonra alınan önlem, gelecekte yaşanması muhtemel kazaların engellenmesi yönüyle olaydan önce alınan önlem niteliğindedir.

İş kazaları gerçekleşebilme potansiyelini gösteren bir başka gösterge ramak kala olaylardır. Ramak kala olay mevzuat kapsamında, çalışma ortamında yaralanma ya da maddi hasarlı kaza oluşturma potansiyeli olduğu halde herhangi bir şekilde zarar vermeyen durum olarak tanımlanmıştır (İSG Risk Değerlendirmesi Yönetmeliği madde 4/d). 6331 sayılı ISG kanunda işverenin görevleri arasında işyerinde meydana gelen ramak kala olayların raporlanmasından bahsetmektedir. (6331 Sayılı ISG Kanunu madde 14). Risk değerlendirmesi çalışmalarının tehlikelerin tanımlanması safhasında ramak kala olay kayıtlarının toplanmasının kanuni zorunluluğundan bahsedilmiştir (İSG Risk Değerlendirmesi Yönetmeliği madde $8 / \mathrm{m}$ ). Yine risk değerlendir- 
mesinin revizyonu için gerekli olan kriterler de ramak kala olayın önemi vurgulanmıştır (İSG Risk Değerlendirmesi Yönetmeliği madde 12/ç).

İşletme içerisinde yaşanan ramak kala olaylar ve iş kazaları arasındaki oran üzerine literatürde yapılan çalışmalar mevcuttur. Herbert W. Heinrich'in 1931 yılında yayınladığı kitabında bahsettiği araştırma sonuçları ramak kala olayın önemini bir kez daha vurgulamaktadır. Herbert W. Heinrich 75.000 adet yaralanma ve hastalık vakasını, 63.000 aktüeryal ve mühendislik raporunu ve 12.000 sigorta kayıtlarını gözden geçirmiştir (Taşyürek, 2018). Bu araştırmanın sonucunda, bir işyerinde 330 adet iş kazası grubunda; majör etkisi (ölüm, uzuv kaybı vb.) olan kazaların temelinde, 29 adet minör etkisi olan (hafif) yaralanmalı kaza ve bunların da temelinde 300 adet ramak kala olayın meydana geldiğini iddia etmiştir (İnci, 2016). İş güvenliği literatürüne Heinrich Piramit Teorisi olarak kazandırılan kaza piramidi Şekil 1.'de gösterilmiştir.

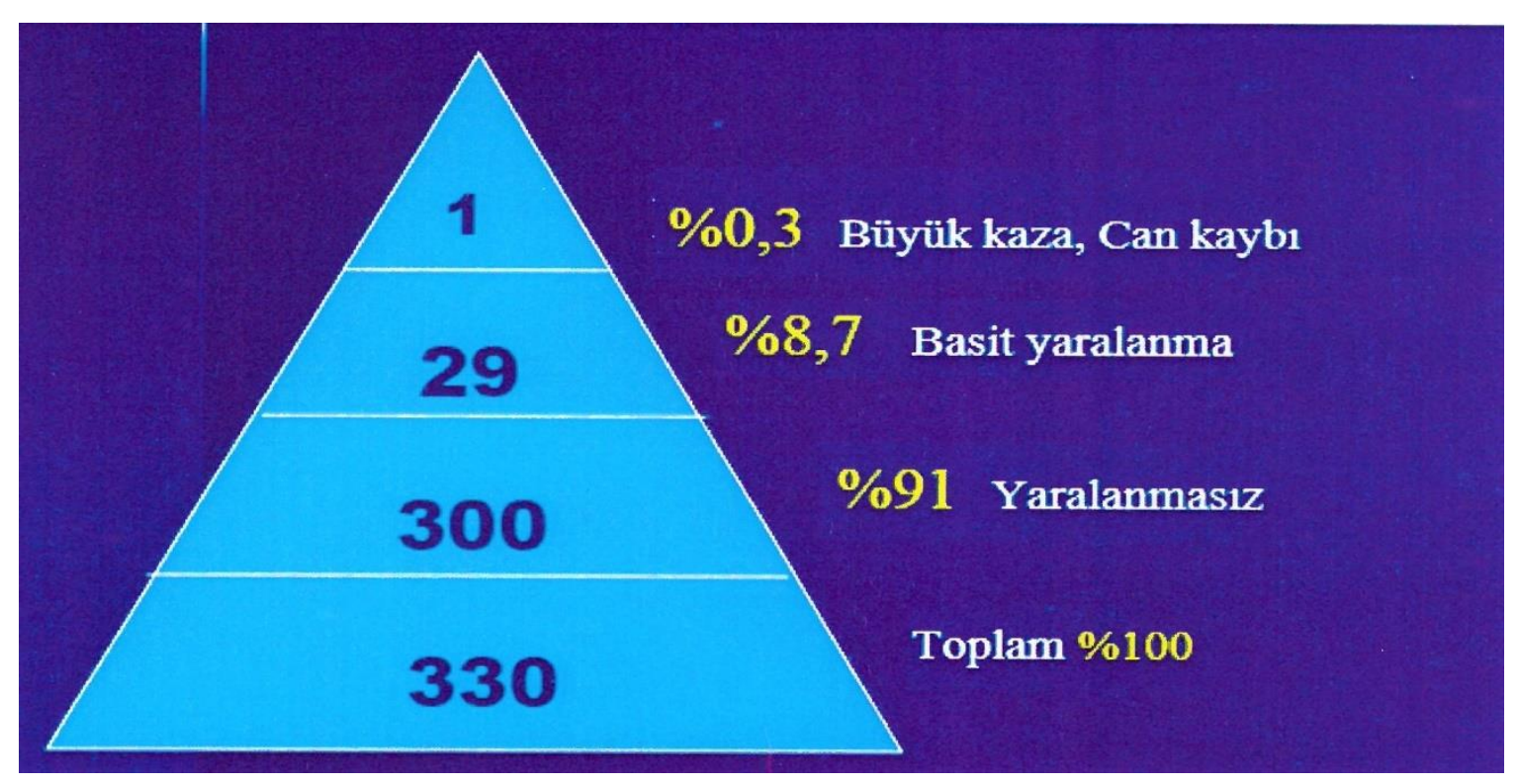

Şekil 1. Herbert W. Heinrich kaza piramidi

1969 yılında Frank Bird Jr., bir işyerinde 641 adet iş kazası grubunda; majör etkisi (ölüm, uzuv kayb1 vb.) olan kazaların temelinde, 10 adet minör etkisi olan (hafif) yaralanmalı kaza, makine-ekipman kaynaklı 30 adet kaza ve bunların da temelinde 600 adet ramak kala olayın meydana geldiğini öne sürmüştür (İnci, 2016). Frank Bird Jr. kaza piramidi Şekil 2.’de gösterilmiştir. 




Şekil 2. Frank Bird Jr. kaza piramidi

1973 y1lında Type ve Pearson, bir işyerinde 534 adet iş kazası grubunda; majör etkisi (ölüm, uzuv kayb1 vb.) olan kazaların temelinde, iş gücü kayıplı 3 kaza, 50 ilk yardım gerektiren kaza, 80 maddi hasarlı kaza ve bunların da temelinde 400 ramak kala olay olduğunu öne sürmüştür (İnci, 2016). Type ve Pearson kaza piramidi Şekil 3.'de gösterilmiştir.

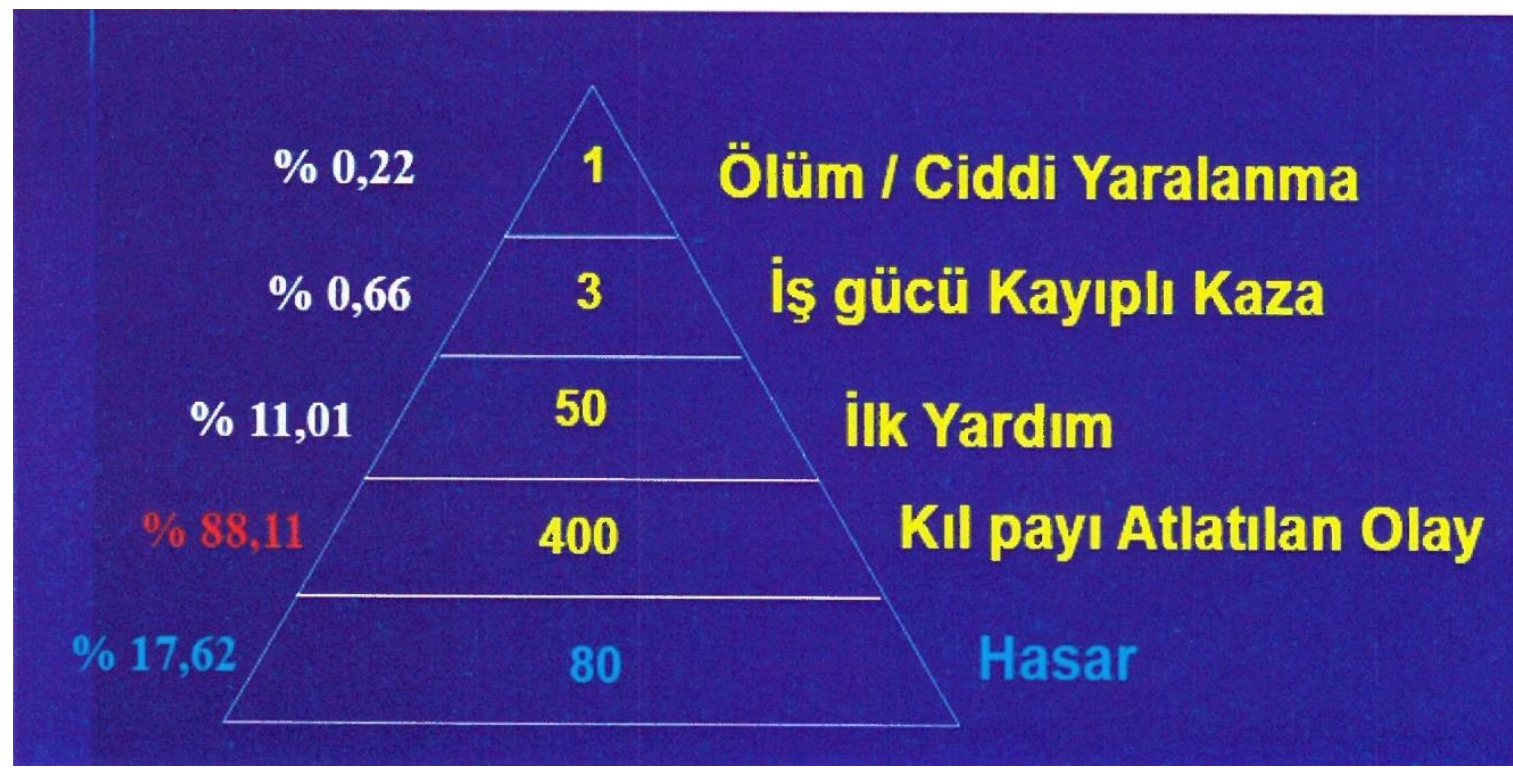

Şekil 3. Type ve Pearson kaza piramidi

Çalışanların işyerinde karşılaştığı tehlikeleri işverene bildirmesi birçok kişinin kurtulmasını sağlayabilir. Personeller, çalışma ortamındaki ekipmanlarda ve yapılarda can güvenliği için tehlike oluşturan durumları çalışan temsilcisine bildirmekle yükümlüdürler. İlaveten tehlikelere karşın alınan tedbirlerde yetersizlik tespit ettiklerinde de çalışan temsilcisine bilgi vermek zorundadırlar (6331 Sayılı İSG Kanunu madde 19/c). Ramak kala olayların raporlanması olası iş kazalarını önleyebilecektir. Personellerin ramak kala olaylarını fark ederek kayıt altına alması, iş güvenliği bilincinin desteklenmesine olumlu katkı sağlamaktadır (Güven, 2018). Çalışanların kendilerini güvende hissetmeleri için, iş güvenliği yönetim sistemi ve mevzuatlar mevcuttur fakat bu bildirim sisteminin işlemesi için çalışanların ramak kala bildirim yapmaları gerekmektedir. Ancak, pek çok kurumda güvenlik kültürünün tam olarak yerleşmemiş olması bildirimlerin önündeki engel- 
lerin başında gelmektedir (Moy vd., 2018). Çünkü ramak kala bildirimleri raporlanması yüksek güvenlik kültürüne sahip işyerlerinin tipik özelliklerindendir (Perttulla, 2016).

Çalışanların ramak kala olayın ayrımını yapamaması, bildirimin ekstra zaman kaybına sebep olacağını düşünmeleri, bildirim de bulunulacağını bilmemeleri, bilse bile arkadaşları tarafından suçlanacağı endişesi gibi nedenler dolayısıyla çalışanlar bildirim yapmamaktadırlar. Ramak kala olayların nedenlerinin detaylı irdelenmesi, olası kazaların önlenmesinde önemli rol oynamaktadır. Çünkü ramak kala olay ile iş kazasının arasındaki tek fark sonuçlarıdır.

Ramak kala olayın ülkemiz mevzuatı kapsamında iş kazası gibi dikkate değer alındığı görülmektedir. Ancak uygulamada ülkemizde ramak kala olaylar hakkında yayınlanan genel kayıtlar veya yayınlara sınırlı sayıdadır (Durduran vd., 2019). İş kazalarının aksine "az kalsın oluyordu" diye tanımlanan ramak kala olaylar, inşaat sektöründe mevcut olup ramak kala durumlarının tekrarlanmaması için herhangi bir kayıt tutulmamaktadır (Odabaş, 2019).

\section{Materyal ve Yöntem}

\subsection{Araştırmanın Amacı}

$\mathrm{Bu}$ çalışmanın amacı katılımcıların ramak kala olaya ilişkin algı düzeylerinin demografik özelliklere göre anlamlı bir farklılığın varlığını belirlemektir.

\subsection{Araştırma Yöntem}

$\mathrm{Bu}$ araştırmada, ramak kala olay ile ilgili literatür taraması yapılarak ve iş güvenliği mevzuatı araştırılarak bilgiler toplanmış ve toplanan bilgiler doğrultusunda anket soruları hazırlanmıştır. Hazırlanan anket soruları Ek 1'de verilmiştir. Bu çalışma betimsel araştırma çalışması olup, tarama (anket) ve karşılaştırmalı araştırma yöntemleri kullanılmıştır.

\subsection{Veri Toplama Araçları}

Bu çalışmada, ramak kala olay ile ilgili bilgi düzeyini değerlendirmek ve farkındalık yaratmak amacıyla 2 bölümden oluşan bir anket formu düzenlenmiştir. Anket çalışanlar ile yüz yüze görüşülerek gerçekleştirilmiştir. Yüz yüze yapılan anketler elektronik ortamda yapılan anketlere göre daha güvenilir sonuçlar ortaya çıkarabilmektedir.

Anketin ilk kısmında katılımcıların demografik özelliklerinin (yaş, medeni durum, cinsiyet, öğretim düzeyi ve mesleki tecrübe) tespiti amacıyla 5 soru bulunmaktadır. Diğer kısımda ise ramak kala olay hakkında çal1şanların bilgi düzeyleri ve farkındalıklarını ölçmek üzere 7 adet soru yer almaktadır. Anketin birinci sorusunda (iş kazası yaşama durumu) 2'li Likert ölçeği (Evet, Hayır) kullanılmış olup anketin diğer sorularında 3’lü Likert ölçeği (Evet, Hayır ve Bilgim yok) kullanılmıştır.

\subsection{Katılımcilar}

Araştırma hedef yanıtlayıcı kitlesi olarak, Çanakkale ilindeki inşaat projelerinde görevli çalışanlar belirlenmiştir. Ankete 130 çalışan katılmış ancak 5 çalışan anketi tamamlamak istememiştir. Toplamda 125 çalışan ile yapılan anketler değerlendirmeye alınmıştır. Araştırmaya katılan seçili çalışanların demografik özellikleri katılımcıların demografik özellikleri ve anket sorularına ilişkin bulgular başlığı altında detaylandırılmıştır.

\subsection{Veri Analizi}

Bu çalışmada, elde edilen dataların geçerlilik ve güvenirlilik analizi SPSS 22.0 ile yapılmıştır. İstatistiksel analizler için anlamlılık sınır değeri $\mathrm{p}<0,05$ kabul edilmiştir (Özdamar vd., 1999). Ankete katılan çalışanların 
demografik özellikleri ve anket sorularına ilişkin bulgular frekans ve yüzde ölçüleri kullanılarak tablolar halinde sunulmuştur.

Bağımlı değişken olan demografik özellikler ile bağımsız değişken olan ramak kala anket soruları ortalaması arasında anlamlı farklılıkların olup olmadığını kıyaslamak için parametrik testlerden olan bağımsız örneklem t-testi ve tek yönlü varyans analizi uygulanmıştır.

\section{Bulgular ve Tartışma}

\subsection{Katılımcıların Demografik Özellikleri ve Anket Sorularına İlişkin Bulgular}

Araştırmaya Çanakkale ilinde inşaat sektöründe görevli 130 çalışan katılmış olup, 5 çalışan anketi tamamlamak istememiştir. 125 çalışanın anketi geçerli kabul edilmiştir. Katılımcılara ait demografik özelliklerin frekans (f) ve yüzdeleri (\%) Tablo 1'de gösterilmiştir.

Tablo 1

Demografik özelliklerin frekans ve yüzdeleri

\begin{tabular}{|c|c|c|c|}
\hline \multicolumn{2}{|c|}{ Demografik Özellikler } & \multirow{2}{*}{$\frac{\mathrm{f}}{7}$} & \multirow{2}{*}{$\begin{array}{c}\% \\
5.6\end{array}$} \\
\hline & Kadın & & \\
\hline & Erkek & 118 & 94.4 \\
\hline \multirow{3}{*}{ Medeni Durumu } & Evli & 38 & 30.4 \\
\hline & Bekâr & 87 & 69.6 \\
\hline & 18-30 yaş aralığı & 38 & 30.4 \\
\hline \multirow[t]{3}{*}{ Yaş } & $31-50$ yaş aralığ & 79 & 63.2 \\
\hline & 50 yaş ve üzeri & 8 & 6.4 \\
\hline & İlkokul / Ortaokul & 27 & 21.6 \\
\hline \multirow[t]{3}{*}{ Öğretim Düzeyi } & Lise & 52 & 41.6 \\
\hline & Üniversite & 46 & 36.8 \\
\hline & 3 yildan az & 50 & 40 \\
\hline \multirow[t]{2}{*}{ Mesleki Tecrübe } & $3-5$ yıl aralığg & 58 & 46.4 \\
\hline & 5 y1ldan fazla & 17 & 13.6 \\
\hline
\end{tabular}

Ankette ramak kala olay hakkında çalışanların bilgi düzeylerini ve farkındalıklarını ölçmek üzere 7 adet soru yer almaktadır. Anketin sadece 1. sorusunda 2'li Likert ölçeği (Evet, Hayır) kullanılmış olup diğer sorular da 3'lü Likert ölçeği (Evet, Hayır ve Bilgim yok) kullanılmıştır. Anket sorularının frekans ve yüzdeleri Tablo 2'de gösterilmiştir. (Ek 1). Anket sonuçlarına göre en yüksek ortalaması olan soru, 1. soru (2.30) ve en düşük ortalaması olan soru, 6. soru (1.82) olarak tespit edilmiştir. 
Tablo 2

Anket sorularının frekans ve yüzdeleri

\begin{tabular}{clcccccc}
\hline \multirow{2}{*}{ Soru No } & \multicolumn{2}{c}{ Evet } & \multicolumn{2}{c}{ Hayır } & \multicolumn{2}{c}{ Bilgim yok } & Ort. \\
\cline { 2 - 8 } & $\mathrm{f}$ & $\%$ & $\mathrm{f}$ & $\%$ & $\mathrm{f}$ & $\%$ & $\overline{\mathrm{X}}$ \\
\hline 1. Soru & 17 & 13.6 & 54 & 43.2 & 54 & 43.2 & 2.30 \\
2. Soru & 39 & 31.2 & 18 & 14.4 & 68 & 54.4 & 2.23 \\
3. Soru & 41 & 32. & 17 & 13.6 & 67 & 53.6 & 2.21 \\
4. Soru & 40 & 32.0 & 22 & 17.6 & 63 & 50.4 & 2.18 \\
5. Soru & 16 & 12.8 & 93 & 74.4 & 16 & 12.8 & 2.00 \\
6. Soru & 23 & 18.4 & 102 & 81.6 & & & 1.82 \\
7. Soru & 30 & 24.0 & 55 & 44.0 & 40 & 32.0 & 2.08 \\
\hline
\end{tabular}

\subsection{Bağımsız t-Testi ve Tek Yönlü Varyans Analizine İliş̧kin Bulgular}

7 maddelik anket ölçeğinin Cronbach Alpha güvenirlik katsayısı $\alpha=0.717$ gibi güvenilir sayılan bir değer çıkmıştır. Tablo 3'de çalışanların cinsiyet ve medeni durum değişkenlerine göre bağımsız t-testi sonuçları gösterilmiştir.

Tablo 3

Anketin cinsiyet ve medeni durum değişkenlerine göre Bağımsız t-Testi sonuçları

\begin{tabular}{llcccc}
\hline Gruplar & $\mathrm{N}$ & $\overline{\mathrm{X}}$ & $\mathrm{Sd}$ & $\mathrm{t}$ & $\mathrm{p}$ \\
\hline Kadın & 7 & 1.78 & .49 & & \\
Erkek & 118 & 2.14 & .44 & -2.08 & $.04^{*}$ \\
Evli & 38 & 2.08 & .52 & & \\
Bekâr & 87 & 2.13 & .43 & -.67 & $.50^{*}$ \\
\hline $\mathrm{p}<.05^{*}, \mathrm{p}=.05$ & & & & &
\end{tabular}

Tablo 3'den görüldüğü üzere anketten elde edilen sonuçlar cinsiyet açısından incelendiğinde, erkeklerin ortalaması ( $\overline{\mathrm{X}}=2.14)$, kadınların ortalaması $(\overline{\mathrm{X}}=1.78)$ 'dir. Yapılan $\mathrm{t}$ testine göre kadın ile erkek çalışanların test ortalamaları arasında istatistiksel olarak erkek çalışanlar lehine anlamlı fark belirlenmiştir $\left[\mathrm{t}_{(123)}=-2.08\right.$; $\mathrm{p}<.05]$. Çalışanların anket sonuçları medeni durumlarına göre kıyaslandığında ise, bekâr olanların ortalaması $(\overline{\mathrm{X}}=2.13)$ ve evli olanların ortalaması $(\overline{\mathrm{X}}=2.08)$ arasında bekâr olanların lehine anlamlı fark gözlenmiştir $\left[\left(\mathrm{t}_{(123)}=-.67 ; \mathrm{p}=.05\right]\right.$.

Tablo 4

Anketin yaş, eğitim düzeyi ve mesleki tecrübe değişkenlerine göre ortalama ve standart sapma sonuçları

\begin{tabular}{ccccc}
\hline & & $\mathrm{N}$ & $\overline{\mathrm{X}}$ & SS \\
\hline \multirow{3}{*}{ Yaş } & $18-30$ yaş arası & 38 & 1.93 & .48 \\
& 31-50 yaş aras1 & 79 & 2.17 & .42
\end{tabular}




$\begin{array}{lcccc} & 50 \text { yaş üzeri } & 8 & 2.43 & .26 \\ \text { Eğitim } & \text { İlkokul/Ortaokul } & 27 & 2.24 & .41 \\ \text { Düzeyi } & \text { Lise } & 52 & 2.18 & .43 \\ & \text { Üniversite } & 46 & 1.98 & .47 \\ & 3 \text { yıldan az } & 50 & 2.00 & .43 \\ \text { Mesleki } & 3-5 \text { yıl arası } & 58 & 2.19 & .46 \\ \text { Tecrübe } & 5 \text { yıldan fazla } & 17 & 2.20 & .43 \\ & & & & \end{array}$

Tablo 4'den görüldüğü üzere anket sonuçları çalışanların; yaş değişkeni açısından incelendiğinde ortalamalar $\overline{\mathrm{X}}=1.93-2.43$, eğitim düzeyi açısından incelendiğinde ortalamalar $\overline{\mathrm{X}}=1.98-2.24$ ve mesleki tecrübe açısından incelendiğinde ortalamalar $\overline{\mathrm{X}}=2.00-2.20$ olarak tespit edilmiştir.

Tablo 5

Anketin yaş, eğitim düzeyi ve mesleki tecrübe değişkenlerine göre Tek Yönlü Varyans analizi sonuçları

\begin{tabular}{|c|c|c|c|c|c|c|c|}
\hline & $\begin{array}{l}\text { Varyansin } \\
\text { kaynağ1 }\end{array}$ & $\begin{array}{l}\text { Kareler } \\
\text { toplamı }\end{array}$ & $\mathrm{Sd}$ & $\begin{array}{l}\text { Kareler } \\
\text { ortala- } \\
\text { ması }\end{array}$ & $\mathrm{F}$ & $\mathrm{p}$ & Anlamlı fark \\
\hline \multirow{2}{*}{ Yaş } & Gruplar arası & 2.34 & 2 & 1.16 & \multirow{2}{*}{6.13} & \multirow{2}{*}{$.003 *$} & \multirow{2}{*}{$\begin{array}{r}18-30 \text { ile } 31-50 \text { yaş arası } \\
18-30 \text { ile } 50 \text { yaş üzer }\end{array}$} \\
\hline & Gruplar içi & 23.6 & 122 & .19 & & & \\
\hline \multirow{2}{*}{$\begin{array}{l}\text { Eğitim } \\
\text { Düzeyi }\end{array}$} & Gruplar aras1 & 1.54 & 2 & .77 & \multirow{2}{*}{3.91} & \multirow{2}{*}{$.020^{*}$} & \multirow{4}{*}{$\begin{array}{l}\text { İlkokul/Ortaokul ile } \\
\text { Üniversite }\end{array}$} \\
\hline & Gruplar içi & 23.95 & 122 & .20 & & & \\
\hline \multirow{2}{*}{$\begin{array}{l}\text { Mesleki } \\
\text { Tecrübe }\end{array}$} & Gruplar arası & 1.13 & 2 & .57 & \multirow{2}{*}{2.84} & \multirow{2}{*}{.062} & \\
\hline & Gruplar içi & 24.35 & 122 & .20 & & & \\
\hline
\end{tabular}

Tablo 5'den anlaşı1dı ğ üzere ez az iki yaş seviyesi arasında istatistiksel olarak anlamlı bir fark belirlenmiştir $\left[\mathrm{F}_{(2,122)}=6.13, \mathrm{p}=.003\right]$. Anlamlı farkın hangi yaşlar arasında olduğunu anlamak için LSD çoklu karşılaştırma testi yapılmıştır. Anlamlı farkın 18-30 - 31-50 yaş arasında ( $\mathrm{p}=.003)$ 31-50 yaş lehine ve 18-30 - 50 yaş üzeri arasında ( $\mathrm{p}=.003) 50$ yaş üzeri lehine olduğu görülmüştür. Hesaplanan etki büyüklüğü Eta-kare $\left(\eta^{2}=.05\right)$ sonucuna göre bu farklılı̆̆ın orta düzeyde etkili olduğu belirlenmiştir.

\section{Sonuçlar}

Çanakkale ili inşaat sektöründe görevli 125 çalışana uygulanan anket sonucunda elde edilen veriler SPSS 22.0 ile analiz edilmiştir. Soruların güvenirlik analizi $\alpha=0.717$ olarak bulunmuştur. Çalışanların yarı sayısının fazlasında, ramak kala olay olgusu konusunda farkındalığa sahip olmadıkları ve bilgi yetersizliği olduğu belirlenmiştir. Bunun nedeni, katılımcılara ramak kala olay hakkında eğitim verilmemesinden 
kaynaklanabilir. Çalışma koşulları bakımında güvenli iş yeri oluşturulsa bile çalışanlarda güvenlik kültürü oluşmadığı sürece iş kazalarını tamamen önlemek mümkün olmamaktadır. Güvenlik kültürü bilincinin oluşturulmasında, iş sağlığı ve güvenliği eğitimleri elzemdir. İşverenler, çalışanlarına özellikle ramak kala olay olgusu hakkında rutin aralıklarla eğitim aldırmaları önerilmektedir. Uzman kişilerin ramak kala olay konusunda vereceği eğitimlerin yanı sıra işverenler görsel uyarı levhaları, poster çalışmaları ile çalışanlarda ramak kala olay bilinç düzeyi arttırılması önerilmektedir. Ayrıca işbaşı konuşmalarında (toolbox), ramak kala olayla ilgili bilinç düzeyini arttırıcı bilgilendirmelerin yapılması önerilmektedir.

Katılımcıların demografik özellikleriyle ramak kala olay bilgisini ölçen anket sorularının cevaplandırılmasında anlamlı ilişkinin varlığı için yapılan inceleme sonucunda cinsiyet, medeni durum ve yaş değişkeninin ramak kala olay bilgisi ölçen anket sorularının cevaplandırılmasında anlamlı etkisi olduğu belirlenmiştir. Katılımcıların \%93.60'nın 50 yaş altında olması ve \%78.40'ünün lise ve üzeri eğitim düzeyine sahiptir. Buna göre her eğitim düzeyinden itibaren her yaştaki kişilere iş sağlı̆̆ 1 ve güvenliği eğitimleri verilmesi ve ayrıca ramak kala olayla ilgili farkındalık oluşturulması önerilmektedir. Çalışma sonucu elde edilen bulgular örneklemle sınırlıdır. Örneklem, genişletilerek ulusal ölçekte katılımcıyı kapsaması sektör düzeyinde anlamlı sonuçlara ulaşılacağı düşünülmektedir.

\section{Teşekkür}

Bu çalışma Çanakkale Onsekiz Mart Üniversitesi Bilimsel Araştırmalar Proje Birimi tarafindan desteklenmiştir. Proje No: FYL-2020-3180.

\section{Yazar Katkıları}

Orkun DALYAN: Veri toplamış ve makaleyi yazmıştır.

Mehmet PİŞKINN: Analizi planlamış, tasarlamış ve gerçekleştirmiştir.

\section{Çıkar Çatışması}

Yazarlar çıkar çatışması bildirmemişlerdir.

\section{Kaynaklar}

Alli, B. O. (2008). Fundamental principles of occupational health and safety. (2. bs.). Geneva: ILO Yayınları.https://www.ilo.org/wcmsp5/groups/public/---dgreports/---dcomm/---publ/document/ publication/wcms_093550.pdf

Anonim. (2011). Theory of accident causes. Erişim adresi: https://iloencyclopaedia.org/part-viii12633/accident-prevention/item/894-theory-of-accident-causes

Durduran, Y., Demir, L. S., Uyar, M., Demirtaş, A., Erdoğan, A., ve Arbağ, H. (2019). Sağllk çalışanlarında iş kazası ve ramak kala olaylara retrospektif bakış. Kocatepe Tıp Dergisi, 20 (3), 131-136. Erişim adresi: https://doi.org/10.18229/kocatepetip.595071

Güven, S. (2018). Ramak kala raporlama. Erişim adresi: https://www.hurriyet.com.tr/ik-yeniekonomi/ramak-kala-raporlama-40737127

İnci, N. (2016). Risk yönetimi ve değerlendirmesi. Erişim adresi: https://docplayer.biz.tr/36721215Degerlendirilmesi-amac.html

Koçak, D,. Eravcı, D. B., Ayan, B., Çelik, E., ve Akaner, Ö. (2018). İs sağlığı ve güvenliği ILO standartları sağllklı ve güvenli bir çalışma ortamının geliştirilmesi. Ankara: Çalışma ve Sosyal Güvenlik Eğitim ve Araştırma Merkezi Yayınları. http://www.casgem.gov.tr/dosyalar/yayinlar/582/dosya-582-4752.pdf

Moy, E. B., Akkor, A., Aydın, Ö., Çelik, N., Cankuş, B., Can Mamur, S., ve Karagülle, M. (2018). Önemsenmiyor mu? Bilgi eksikliği mi? Ramak kala olaylar. Online Türk Sağl1k Bilimleri Dergisi, 3:70-86. Erişim adresi: https://doi.org/10.26453/otjhs.379758

Odabaş, F. (2019). Inşaat projelerinde ramak kala olaylarının tespiti ve yüksekten düşmelerin önlenmesine yönelik öneri gelişstirilmesi (Yüksek lisans tezi). Erişim adresi: https://tez.yok.gov.tr/UlusalTezMerkezi

Özdamar, K., Odabaşı, Y., Hoşcan, Y., Bir, A. A, Kırcaali-İftar, G., Özmen, A., ve Uzuner, Y., (1999). 
Sosyal bilimlerde araştırma yöntemleri Eskişehir: Anadolu Üniversitesi Yayınları. https://www.researchgate.net/profile/Gonul_Kircaali_Iftar/publication/315608799_Bilim_ve_arastirm a/links/58d52d844585153378585f01/Bilim-ve-arastirma.pdf

Özkılıç, Ö. (2005). İs sağllğ ve güvenliği yönetim sistemleri ve risk değerlendirme metodolojileri Ankara: Türkiye İşveren Sendikaları Konfederasyonu Yayınları. https://1012af86-1cd9-467a-9363265bf75a7743.filesusr.com/ugd/6eefe5_dcaeb8efafd0445a8d2350773b3d5ba2.pdf

Özpınar, S. (2018). Bir üniversite hastanesinin dahili birimlerinde çalışan hemşire ve hekimlerin iş kazaları ve ramak kala olaylara maruz kalma slklı̆g, bildirim durumlarl ve etkileyen etmenlerin incelenmesi (Yüksek lisans tezi). Erişim adresi: https://tez.yok.gov.tr/UlusalTezMerkezi

Perttula, P. (2016). Near misses. Erişim adresi: https://oshwiki.eu/wiki/Near_misses\#Definiti\%EF\%BE\%ADon_of_near_misses

Resmî Gazete. (2006). 5510 sayılı Sosyal Sigortalar ve Genel Săğlk Sigortası Kanunu Erişim adresi: https://www.resmigazete.gov.tr/eskiler/2006/06/20060616-1.htm

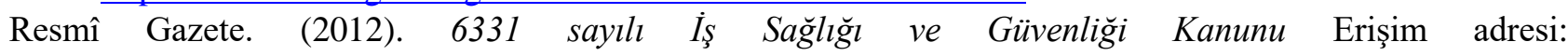
https://www.resmigazete.gov.tr/eskiler/2012/06/20120630-1.htm

Resmî Gazete. (2012). İş Sağlı̆̆ ve Güvenliği Risk Değerlendirmesi Yönetmeliği Erişim adresi: https://www.resmigazete.gov.tr/eskiler/2012/12/20121229-13.htm

Selek Öz, C. ve Nam, D. (2018). Demografik değişkenler ve işle ilgili geçmişin güvenli davranışa etkisi: Gemi inşa sanayiinde bir alan araşstırması. Bilgi Sosyal Bilimler Dergisi, (1), 124-146. Erişim adresi: https://dergipark.org.tr/tr/download/article-file/491551

Tan, F. C. ve Çalışkan, S. (2018). Yöneticilerin iş sağlı̆̆l ve güvenliği uygulamalarına yönelik algılarının analizi üzerine bir araştırma. Karaelmas İş Sağlı̆̆ 1 ve Güvenliği Dergisi, 2 (1), 31-44. Erişim adresi: https://doi.org/10.33720/kisgd.384136

Taşyürek, M. (2018). İş kazalarının çoğunluğu kaza geçiren insanların hatasından mı olur?. Erişim adresi: http://www.guvenlicalisma.org/19617-is-kazalarinin-cogunlugu-kaza-geciren-insanlarin-hatasindanmi-olur

Türk Standartları Enstitüsü. (2008). YTS 18001 İş sağllğg ve güvenliği yönetim sistemleri. Erişim adresi: https://www.turcert.com/standard/ohsas-18001.pdf

WHO. (2017). Dünya Sağlık Örgütü (World Health Organization). Erişim adresi: https://www.who.int/

Yenisar1, B., Mestav, B. ve Öztürk Ö. (2019). Üniversite çalışanlarının iş sağllğ ve güvenliği e ĕitimi konusundaki bilinç düzeylerinin araştırılması. Çanakkale Onsekiz Mart Üniversitesi Fen Bilimleri Enstitüsü Dergisi, 5 (2), 339-355. Erişim adresi: https://doi.org/10.28979/comufbed.515572

Yılmaz, A. İ. (2013). İş sağllğı ve güvenliğinde kaza zinciri teorisinin önemi ile açık işletmelerdeki tehlikeli hareketler ve tehlikeli durumlar. MT Bilimsel Yer Altı Kaynakları Dergisi, 3:27-39. Erişim adresi: https://dergipark.org.tr/tr/download/article-file/366555 
EK 1: Anket Soruları

\section{İşyerlerinde Ramak Kala Bildirimlerinin İş Kazalarına Etkisi ve İnşaat Sektöründe Uygulama}

\section{RAMAK KALA OLAY BİLISİ VE BILLİRIM SISTEMINE ILIŞKIN ANKET FORMU}

Bu anket formu, “Çalışanların Ramak Kala Olay Bilgisi ve Bildirim Sistemine İlişkin” bilgilerinin değerlendirilmesi amacıyla hazırlanmıştır. Ankete vereceğiniz doğru bilgi ve görüşleriniz, iş kazalarının nedenlerinin daha iyi anlaşılmasında ve iş kazalarının çözümüne önemli katkı sağlayacaktır. Bu formda bireyleri tanımlayıcı türde (demografik özellikler) 5 soru, "Çalışanların Ramak Kala Olay Bilgisi ve Bildirim Sistemine İlişkin”" Likert ölçekte de 7 soru bulunmaktadır. Cevaplama yaklaşık 15 dakika sürmektedir. Ankete katılımınız gönüllü olmalıdır. Verdiğiniz cevaplar gizli tutulacak, yalnızca araştırma için kullanılacak, bireysel bilgileriniz kimse ile paylaşılmayacaktır. Bu nedenle ankete adınızı, soyadınızı ve adresinizi yazmayınız. Uygun görmemeniz halinde ankete katılmayabilir ya da anketi cevaplandırmayı sonlandırabilirsiniz.

Zaman ayırdığınız, içten cevaplarınızla araştırmaya ve olası sorunların çözümüne katkı verdiğiniz için teşekkür ederiz.

\section{DEMOGRAFIK ÖZELLIKKLER}

\begin{tabular}{lllllll} 
Cinsiyet & Kadın & $\square$ & Erkek & $\square$ & & \\
Medeni Durumu & Evli & $\square$ & Bekar & $\square$ & & \\
Yaşınız & $18-30$ & $\square$ & $31-50$ & $\square$ & 50 üzeri & $\square$ \\
Eğitim Düzeyi & Üniversite & $\square$ & Lise & $\square$ & illkokul/Ortaokul & $\square$ \\
Mesleki Tecrübe & 3 yıldan az & $\square$ & $3-5$ yll arası & $\square$ & 5 ylldan fazla & $\square$ \\
\hline
\end{tabular}

ANKET SORULARI

1. Ramak kala olay hakkında bilginiz var mı?

Evet $\quad \square$ Hayir $\square$ Bilgim Yok

2. Ramak kala bildirim sisteminiz var mı ?

Evet

Hayır

Bilgim Yok

3. Ramak kala bildirimi gerekli midir ?

Evet

Hayir

Bilgim Yok

4. Ramak kala bildirimleri ile iş kazaları arasında sizce bir bağlantı var mıdır ?

Evet $\square$ Hayır $\square$ Bilgim Yok

5. Daha önce ramak kala bildirimi yaptınız mı ?

Evet

Hayır

Bilgim Yok

6. Daha önce iş kazası yaşadınız mı ?

Evet

Hayır

7. Ramak kala bildirimleri için düzeltici önleyici faaliyet yapılmalı mı ?

Evet

Hayır
Bilgim Yok 